\title{
Hilar Mass
}

National Cancer Institute

\section{Source}

National Cancer Institute. Hilar Mass. NCI Thesaurus. Code C35495.

An abnormal growth located in the hilum of the lung. 